\title{
Ekspresi Kalretinin Pada Diagnosis Sitologi Efusi Pleura dengan Gambaran Sitomorfologi Adenokarsinoma
}

\author{
Syeben Hezer, Indra Wijaya, Ika Pawitra Miranti, Meira Dewi Kusuma \\ Bagian Patologi Anatomi Universitas Diponegoro/ RSUP Dr. Kariadi \\ Jalan dokter Soetomo no 16-18, Semarang 50231. Telp (024) 8441270 Pesawat: 4030 , \\ Email: iapismg@gmail.com
}

\begin{abstract}
ABSTRAK
Metastasis adenokarsinoma adalah kasus yang paling sering dijumpai pada efusi pleura yang disebabkan oleh keganasan. calretinin sampai saat ini digunakan sebagai penanda untuk sel mesothel baik jinak maupun ganas. Calretinin digunakan terutama untuk membedakan mesothelioma dari suatu karsinoma atau metastasis keganasan lainnya. Namun beberapa penelitian membuktikan bahwa kalretinin tidak hanya positif untuk selsel mesothel tetapi dapat pula pada keganasan lain seperti metastasis adenokarsinoma atau squamous sel karsinoma. Penelitian ini bertujuan membuktikan terdapat ekspresi kalretinin pada efusi pleura dengan gambaran sitomorfologi suatu adenokarsinoma. Jenis penelitian ini adalah deskriptif observasional dengan desain cross sectional. Terdapat 20 blok sitologi dari efusi pleura yang memenuhi kriteria kemudian dilakukan pengecatan calretinin. Ekspresi positif ditandai dengan tercatnya inti dan sitoplasma sel yang dicurigai ganas. Ekspresinya dibaca oleh 2 orang spesialis Patologi Anatomi secara blindly. Ekspresi calretinin negatif pada 6 sampel, positif I pada 8 sampel, positif II pada 2 sampel dan positif III pada 4 sampel. Terdapat ekspresi calretinin pada pada efusi pleura dengan gambaran sitomorfologi suatu adenokarsinoma dengan tingkat positivitas yang berbeda-beda, hal ini menunjukan bahwa kalretinin bukan merupakan penanda yang spesifik dan sensitif untuk sel-sel mesothel baik jinak maupun ganas.
\end{abstract}

Kata kunci: Calretinin, Sitologi efusi, Adenokarsinoma

\begin{abstract}
Metastatic adenocarcinoma is the most common case in pleural effusions caused by malignancy. Up to recently, calretinin is used as marker for benign and malignant mesothelial. Calretinin used primarily to distinguish mesothelioma from metastatic carcinoma or other malignancies. However, some studies shown that not only calretinin positive for mesothelial cells but can also be in other malignancies such as metastatic adenocarcinoma or squamous cell carcinoma. This study aims to prove there are calretinin expression in pleural effusions with cytomorphologic adenocarcinoma. This study is descriptive analytic study using cross sectional design. Twenty paraffin embedded cells of pleural effusion that meet the criteria were stained with calretinin. Positive reaction was defined as nuclear and cytoplasmic staining. The immunoreactivity was evaluated blindly by two pathologists. Calretinin staining was negative in 6 samples, positive I in 8 samples, positive II in 2 samples and positive III in 4 samples. There was calretinin expression in the pleural effusion with cytomorphologic adenocarcinoma on different levels of positivities, this shows that calretinin is not a specific and sensitive marker for benign and malignant mesothel.
\end{abstract}

Keywords : Calretinin, Cytology effusion, Adenocarcinoma

\section{Pendahuluan}

Efusi pleura adalah penumpukan cairan dalam rongga pleura, yang merupakan ruang antara paru-paru dengan dinding dada bagian dalam. Setengah dari penderita kanker mengalami metastasis ke ruang pleura dan menyebabkan terjadinya efusi . Lebih dari $75 \%$ penderita dengan efusi pleura curiga ganas disebabkan oleh metastasis yang berasal dari paru, ovarium atau lymphoma. Metastasis adenokarsinoma adalah 
kasus yang paling sering dijumpai, pada pria paling sering berasal dari paru sedangkan pada wanita terutama berasal dari ovarium (Cancer Net., 2012; Ensani et al., 2011; Muduly et al., 2011).

Calretinin termasuk keluarga EF-hand merupakan suatu calcium-binding protein, keluarga EF-hand yang banyak dikenal yaitu calbindin-D28k (CB), calretinin (CR) and parvalbumin (PV). Calretinin pertama kali dikemukakan oleh Rogers pada tahun 1987 dengan meneliti sel-sel retina, penamaannya berdasarkan kesamaan struktur dengan Calbindin D28k, terletak pada kromosom 16. Calretinin berupa struktur helix-loop-helix yang mempunyai 269 - 271 asam amino dan berisi 6 rantai EF, 4-rantainya mengikat $\mathrm{Ca} 2^{+}$dengan afinitas tinggi, 1 rantai mengikat $\mathrm{ca}^{+}$dengan afinitas rendah dan 1 rantai non-fungsional. Calretinin juga mempunyai afinitas terhadap ion $\mathrm{cu} 2^{+}$(Robinson et al., 2005; Kuznicki et al., 1995). Calretinin banyak ditemukan pada jaringan saraf pusat dan perifer, di sel-sel retina, pada sel-sel mesothel, kelenjar ekrin kulit, tubulus ginjal, sel leydig dan sertoli dari testis, endometrium, stroma ovarium dan sel kortical ginjal (Bobrowicz et al. 2011; Invitrigen 2007; Lee et al., 2006; Hiradfar et al., 2012) Calretinin berperan dalam buffer fisiologis ion kalsium sitosol, transportasi kalsium dan perlindungan terhadap kelebihan ion kalsium (Hiradfar et al., 2012).

Imunihistokimia calretinin sampai saat ini digunakan sebagai penanda untuk sel mesothel baik jinak maupun ganas. Menurut laporan lebih dari $95 \%$ positif pada mesothelioma tipe epitheloid. Calretinin digunakan terutama untuk membedakan mesothelioma dari suatu karsinoma atau metastasis keganasan lain terutama yang memiliki gambaran mirip mesothelioma dari jaringan biopsi atau sitologi (Miller, 2003). Namun penelitian lain membuktikan bahwa kalretinin tidak hanya positif untuk sel-sel mesothel tetapi dapat pula pada keganasan lain seperti metastasis adenokarsinoma atau squamous sel karsinoma. Penelitian yang dilakukan oleh Barberis dengan pewarnaan anticalretinin menunjukan $100 \%$ positif pada mesothelioma maligna dan $23 \%$ yang positif pada metastasis adenokarsinoma pada cairan pleura. Sebaliknya penelitian yang dilakukan Simsir $27 \%$ positif pada reaktif mesothelial, $35 \%$ pada mesothelioma maligna dan $48 \%$ positif pada adenokarsinoma (Chhieng et al., 2000). Menurut Nelson calretinin dapat positif $6-10 \%$ pada adenokarsinoma paru, $31-38 \%$ pada serous karsinoma dan $0-4 \%$ pada renal sel karsinoma, sedangkan squamous sel karsinoma dari paru calretinin dapat positif pada $23-39 \%$ kasus dengan tingkat positivitas yang berbedabeda (Ordonez, 2005).

Penelitian ini bertujuan membuktikan terdapat ekspresi kalretinin pada efusi pleura dengan gambaran sitomorfologi suatu adenokarsinoma.

\section{Metode}

Penelitian ini menggunakan metode deskriptif observasional dengan desain cross sectional, ruang lingkup disiplin penelitian ini meliputi bidang ilmu Patologi Anatomi, khususnya sitologi cairan dan imunositokimia yang dilakukan di laboratorium Patologi Anatomi FK UNDIP/ RSDK Semarang.

Populasi penelitian meliputi penderita yang dirawat inap di Rumah Sakit Umum Dr. Kariadi Semarang periode januari 2012 sampai desember 2013 dengan diagnosis klinis efusi pleura yang disebabkan oleh metastasis adenokarsinoma dari paru atau tempat lain. Pemilihan sampel dilakukan dengan teknik sistimatik yaitu dengan memilih blok sitologi yang memberi gambaran keganasan, serta memenuhi kriteria inklusi yaitu penderita yang dirawat inap di RSDK Semarang, mempunyai blok sitologi dengan gambaran metastasis adenokarsinoma, blok sitologi masih dapat dipotong 2-5 kali dengan tebal 2-3mm, dan kriteria eksklusi blok sitologi rusak atau tidak terdapat sel, blok sitologi sudah tipis dan hanya dapat dipotong 2 kali saja, Sediaan sitologi yang tidak dibuat blok. Didapatkan 20 blok yang memenuhi kriteria inklusi dan eksklusi.

Blok dipotong dan dilakukan pengecatan immunositokimia calretinin. Ekspresi calretinin merupakan skor ekspresi calretinin positif pada sel ganas, dengan pemeriksaan imunositokimia, berdasarkan persentase sel ganas yang tercat pada inti dan sitoplasma (Ensani et al., 2011; Roberts et al., 2001; Foster et al., 2001), yaitu negatif = tidak tampak sel ganas yang tercat, positif $\mathrm{I}=1-25 \%$ tercat pada sel ganas, positif II $=26-50 \%$ tercat pada sel ganas, positif III $=51$ $100 \%$ tercat pada sel ganas (Chhieng et al., 2000; Roberts et al., 2001; Foster et al., 2001; Ordonez 
et al., 2006). Dengan melihat pada 10 lapang pandang menggunakan pembesaran 400x secara acak, kemudian dibaca oleh dua dokter spesialis Patologi Anatomi secara blindly selanjutnya dibandingkan dengan menggunakan test Kappa. Slide dibaca menggunakan mikroskop Olympus PX51, pembesaran lensa okuler 10x dan lensa obyektif 40x.

Sitomorfologi adenokarsinoma pada cairan efusi berupa smear yang hiperseluler, dengan selsel ganas yang tersebar atau berkelompok member gambaran dua atau tiga dimensi, ada pula yang tersusun asiner, sel tersebut memiliki inti yang pleomorfik, hiperkromatik, anak inti prominen, mitosis abnormal dapat ditemukan, serta kadang ditemukan sel-sel dengan bentukan yang aneh/ bizarre (Gray W \& Kocjan, 2010).

\section{Hasil dan Pembahasan}

Penelitian ini meggunakan 20 sampel blok sitologi, kemudian dilakukan pengecatan calretinin. Hasil pengecatan di dibaca oleh dua dokter spesialis Patologi Anatomi, independen selanjutnya dibandingkan dengan menggunakan test Kappa. Nilai kappa yang diperoleh adalah 0,88 .

Tabel 1. Nilai Mean, median dan modus dari ekspresi Calretinin

\begin{tabular}{cccc}
\hline & Mean & Media & Modus \\
\hline $\begin{array}{c}\text { Ekspresi } \\
\text { Calretinin }\end{array}$ & 2,2 & 2,0 & 2 \\
\hline
\end{tabular}

Pada tabel 1. terlihat nilai mean, median dan modus ekspresi calretinin dan pada 20 sampel blok sitologi dengan penilaian $1=$ negatif, $2=$ positif I, $3=$ positif II dan $4=$ positif III.

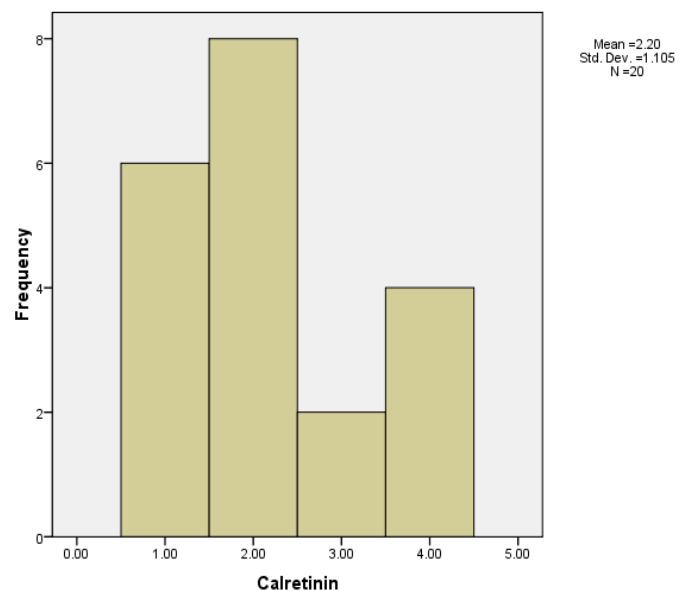

Tabel 2. Frekuensi ekspresi calretinin

Pada tabel 2 terlihat bahwa frekuensi ekspresi calretinin terbanyak adalah positif I yaitu sebanyak 8 sampel atau $40 \%$, sedangkan yang paling sedikit positif II sebanyak 2 sampel atau $10 \%$.

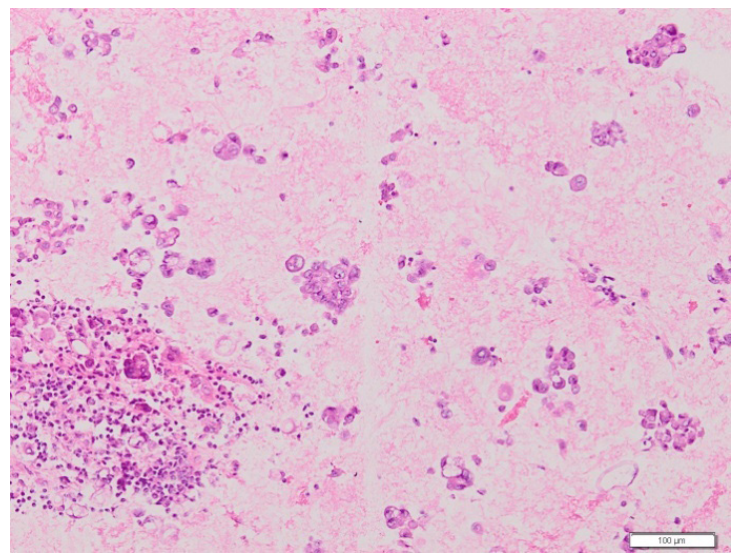

Gambar 1. Pengecatan HE pada blok sitologi dengan pembesaran 20x, panah menunjukan kelompok sel yang mencurigakan keganasan 


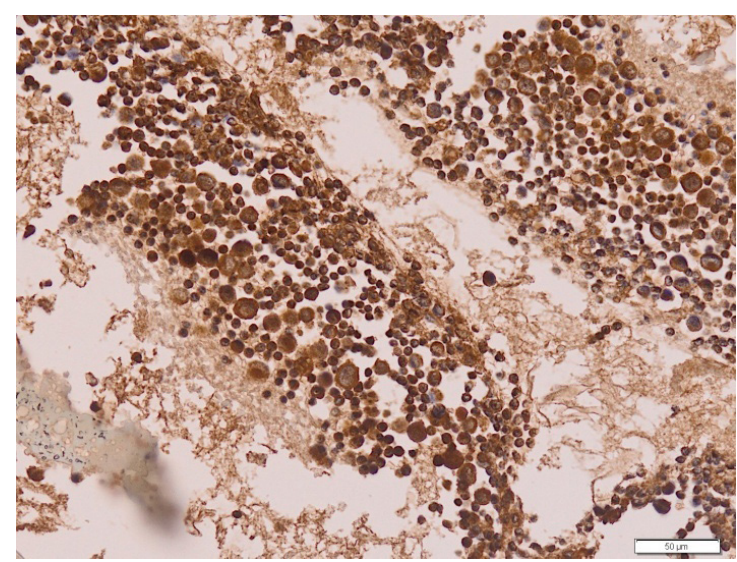

Gambar 2. Pengecatan calretinin pada blok sitologi dengan pembesaran 200x, menunjukan kontrol positif pada sel-sel mesothel

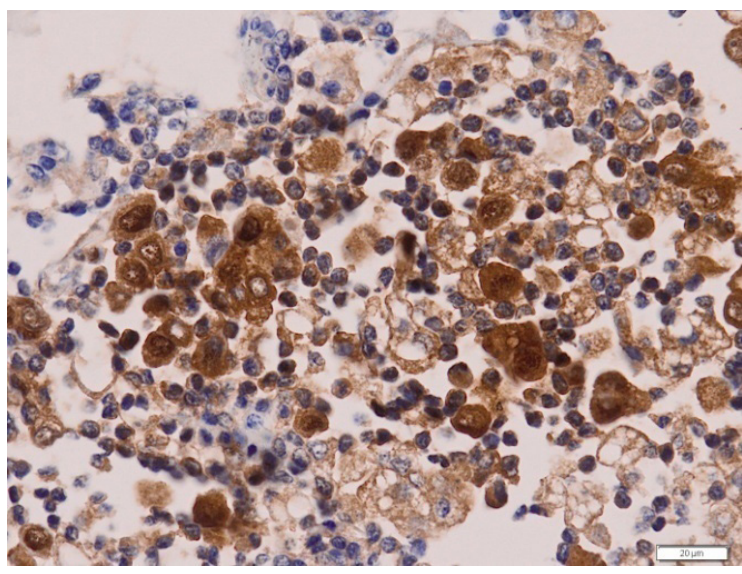

Gambar 3. Pengecatan calretinin pada blok sitologi dengan pembesaran 400x, panah menunjukan sel-sel curiga ganas tercat positif

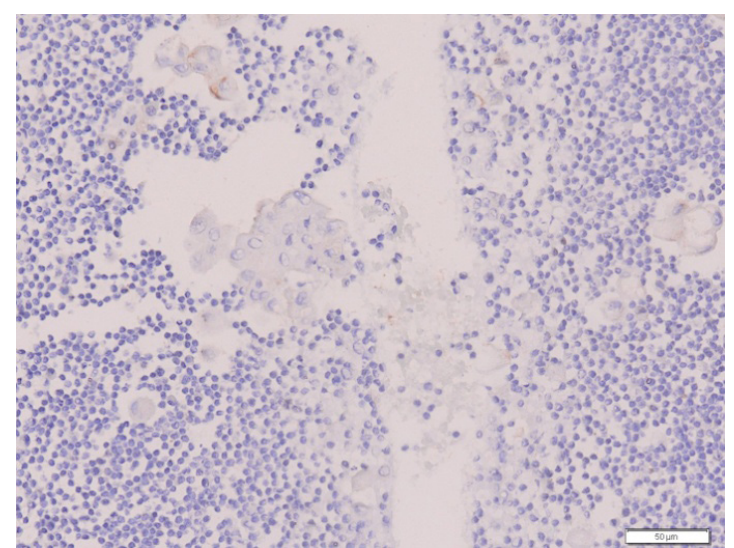

Gambar 4. Pengecatan calretinin pada blok sitologi dengan pembesaran 200x, panah menunjukan kelompok sel curiga ganas tidak tercat (-)

\section{Pembahasan}

Dari 20 sampel yang digunakan, 14 sampel berekspresi positif atau $70 \%$, sedangkan 6 sampel atau $30 \%$ negatif. Dari 14 sampel tersebut 8 sampel atau $40 \%$ positif I, 2 sampel atau $10 \%$ positif II dan 4 sampel atau $20 \%$ positif III . Nilai positif ditandai dengan tercatnya inti dan sitoplasma sel yang dicurigai sebagai sel ganas.

Pada 14 sampel yang bereaksi positif menunjukan sel-sel tersebut mengandung calretinin, dengan tingkat positivitas yang berbeda-beda sedangkan pada 6 sampel yang negatif menunjukan sel-sel tersebut tidak mengandung kalretinin. Secara teoritis calretinin terdapat terutama pada sel-sel saraf pusat dan perifer juga pada sel mesothel normal maupun keganasan (Kuznicki et al., 1995), Namun pada beberapa penelitian menunjukan adenocarcinoma, squamous cell carcinoma atau tumor lain juga dapat bereaksi positif pada pewarnaan dengan calretinin (Chhieng et al., 2000; Foster et al., 2001).

Pada penelitian ini didapatkan $70 \%$ sampel yang digunakan berekspresi positif, hal ini menunjukan bahwa kalretinin tidak hanya terdapat pada sel-sel mesothel, tetapi dapat pula ditemukan pada adenokarsinom. Terdapat $20 \%$ dengan nilai positif III atau lebih dari $50 \%$ sel tumor yang ditemukan tercat positif, hasil ini bertentangan dengan apa yang dikemukakan oleh 
Nelson yang mengatakan bahwa meskipun pada adenokarsinoma hasilnya dapat positif namun nilai positivitasnya rendah atau hanya bersifat fokal dibandingkan pada mesothelioma malignan dimana didapatkan positif kuat dan difus pada semua sel ganas (Ordonez, 2005). Terdapat juga hal-hal yang dapat mempengaruhi hasil diagnosis diantaranya antibodi yang digunakan, prosedurnya, serta jumlah sel ganas yang ditemuka, serta yang terpenting adalah gambaran sitomorfologi sel-sel yang didapat benar-benar merupakan gambaran adenokarsinoma bukan suatu mesothel reaktif (Yahya et al., 2013). Kelemahan pada penelitian ini adalah jumlah sel ganas pada tiap sampel tidak sama, sehingga dapat mempengaruhi persentasinya.

Melihat hasil tersebut maka penggunaan kalretinin secara tunggal untuk membedakan mesothelioma dari suatu karsinoma atau metastasis keganasan lain terutama yang memiliki gambaran mirip mesothelioma dari jaringan biopsi atau sitologi perlu dipikirkan lagi. Perlu juga diingat belum ada satu immunohistokimia marker yang benar-benar $100 \%$ spesifik dan sensitif (Relan et al., 2013).

\section{Simpulan}

Terdapat ekspresi calretinin pada pada efusi pleura dengan gambaran sitomorfologi suatu adenokarsinoma dengan tingkat positivitas yang berbeda-beda, hal ini menunjukan bahwa kalretinin bukan merupakan penanda yang spesifik dan sensitif untuk sel-sel mesothel baik jinak maupun ganas.

\section{Saran}

Untuk penelitian selanjutnya disarankan menggunakan sampel yang lebih besar.

\section{Daftar Pustaka}

Bobrowicz TW, Lowendowska E, Stepieh T, Szpak Gm. 2011. Differential expression of calbindin D28k, calretinin and parvalbumin in the cerebellum of pups of ethanol-treated female rats. Folia Neuropathol , 49 (1): 47-55

Cancer Net. Fluid Around the Lungs or Malignant Pleural Effusion. [homepage on the Internet]. 2012 [cited 2014 Feb 27]. Available from:,
Oncologist-approved cancer information from the American Society of Clinical Oncology Web site: http://www.cancer.net/ navigating-cancer-care/side-effects/fluidaround-lungs-or-malignant-pleural-effusion.

Chhieng DC, Yen H, Schefer D, Cangiarella Jf, Jagindar J, Chiriboga La, et al. 2000. Calretinin Staining Pattern Aids in the Differentiation of Mesothelioma from Adenocarcinoma in Serous Effusions. American Cancer Society, 90(3):194-200.

Ensani F, Nemetizadeh F, Irvanlou G. 2011. Accuracy of Immunohistochemistery in Evaluation on Malignant Pleura and Peritoneal Effusion. Pol. J Patho, 2:95-100.

Foster MR, Johnson JE, Olson SJ, Allred C. 2001. Immunohistochemical Analysis of Nuclear Versus Cytoplasmic Staining of WT1 in Malignant Mesotheliomas and Primary Pulmonary Adenocarcinomas. Arch Pathol Lab Med , 125:1316-20.

Gray W \& Kocjan C Dyagnostic Cytopathology. 3rd ed. China: Livingstone Elsevier; 2010.

Hiradfar M, Sharifi M, Khajedaluee M, Zabolinejad N, Jamshidi St. 2012. Calretinin Immunohistochemistery: An Aid in the Diagnosis of Hirschsprung's Disease. Iran J Basic Med Sci., 15(5):1053-9.

Invitrigen A. Rabbit anti-Calretinin. [homepage on the Internet]. 2007 [cited 2014 Feb 27]. Available from: http://tools.lifetechnologies. com/content/sfs/manuals/081211_Rev0808. pdf

Kuznicki, J, Wang TL, Martin BM, Winsky L, Jacobowitz Dm. 1995, Localization of $\mathrm{Ca} 2+-$ dependent conformational changes of calretinin by limited tryptic proteolysis, Biochem. J . 308:607-12.

Lee ES, Leong AS, Kim YS, Lee Jh, Kim I, Ahn Gh. 2006. Calretinin, CD34, and a-smooth muscle actin in the identification of peritoneal invasive implants of serous borderline tumors of the ovary. Modern Pathology, 19:364-72.

Miller RT. Calretinin. [serial on the Internet]. 2003 [cited 2014 Feb 27]. Available from: /http:// www.ihcworld.com/ newsletter/2003/ focus feb 2003.pdf.

Muduly DK, Deo SV, Kalliapur AA, Shukla. 2011, An Update in the Management of Malignant Pleural Effusion. Indian $J$ Palliat Care, 17(2):98-103 
Ordonez NG, 2005, Immunohistochemical Diagnosis of Epithelioid Mesothelioma An Update, Arch Pathol Lab Med , 129:1407-14.

Ordonez NG, 2006, The diagnostic utility of immunohistochemistry in distinguishing between epithelioid mesotheliomas and squamous carcinomas of the lung: a comparative study. Modern Pathology, 19:417-28.

Relan V, Morrison L, Parsonson K, Clarke Be, Duhig Ee, Windsor Mn, et al. 2013. Phenotype and Karyotype of Human Malignant Mesothelioma Cell Lines. Plos One, 8(3):18 .
Roberts F, Downie IR, Harper CM, Burnett Ra. 2001, Immunohistochemical Analysis Still Has a Limited Role in the Diagnosis of Malignant Mesothelioma. Am J Clin Pathol . 116:25362.

Robinson BW, Lake RA. 2005, Advances in Malignant Mesothelioma, NEJM, 353(15):1591-603.

Yahya ZM, Ali HH, Hussein HG. 2013, Evaluation of the Sensitivity and Specificity of Immunohistochemical Marker in the Differential Diagnosis of Effusion Cytology. Oman Medical Journal, 28(6):410-6. 